Krzysztof FORMICKI ${ }^{1}$, Mieczystaw KOWALEWSKI ${ }^{2}$, Andrzej SOBOCINSSKI', Lucjan TOMASIK ${ }^{1}$, Aleksander WINNICKI ${ }^{1}$

Embryology

\title{
MOTILITY OF HUCHO HUCHO L. SPERMATOZOA AFTER ACTIVATION
}

\section{RUCHLIWOSĆ PLEMNIKÓW GLOWACICY (HUCHO HUCHO L.) PO ARTYWACII}

\author{
${ }^{1}$ Institute of Ichthyology, Academy of Agriculture, Szczecin \\ ${ }^{2}$ Polish Anglers Association Station at Eopusza
}

Observations of the Danube salmon spermatozoa/mo-
tility and spermatocrit were conducted. Sperm was tested
immediately after spawning and during its prolonged storage.

\section{INTRODUCTION}

The specialized literature, so far, has no data on compless studies of Hucho hucho $\mathbb{L}$. spermatozoa and conducted surveys were fragmentary only. Haempel (1913), for example, had observed / motility of Hucho hucho. I. spermatozoa since their activation in water and noted it to last up to $45 \mathrm{sec}$. According to Scheuring (1928), time when Hucho huscho $\mathbb{L}$. spermatozoa stayed motile reached up to $76 \mathrm{sec}$ (progressive motion up to 30 sec.) depending on the spermatozoa quality; geting shorter with prolonged storage of sperm. Pavlik (1957) confirmed Haempel's results, while Harsanyi, cited by/Holčik et al. (1984) found the Hucho hucho L. spermatozoa to be motile up to $120 \mathrm{sec}$ after their activation in water of $10^{\circ} \mathrm{C}$. Analysis of Danube salmon spermatozoa with electron microscope proved their structure to be typical for salmonids, with lack of acrosome and eccentric situation of the flagella in relation to the head (Radziun and Tomasik, 1985).

Difierence in/ conclussions, in just few papers dealing with the Hucho hucho $\mathbb{L}$. spermatozoa mótility problem, induced us to under-take comples, to some extent, 
studies. Besides we wanted to find out if and to what extent observations done by others on fish spermatozoa motility (Nomura, 1964; Yoshida and Nomura, 1972; Holtz et al., 1977), dividing whole motility period into separate phases of progressive motion and pendular motion, can be applied to Hucho hucho L. spermatozoa.

\section{MATERIAL AND METHODS}

Surveys were conducted in 1985 in the Polish Anglers Association Station at Lopuszna and than repeated in 1988, Sperm from 11 and 6, respectively, mature Hucho hucho L. males was analysed. Males, whose ejaculates were tested, were measured and their age determinèd.

Surveys included determination of total motility timesof spermatozoa after getting in touch with water, distinguishing the length of each phase of the motion; namely progressive motion random (turbulent) and circular (quiet) - according to motion's intensity and pendular motion (Fig. 1). For all samples a relative number of active spermatozoa (percent of motility) and a relative volume of spermatozoa within a sperm sample = "spermatocrit" according to the method by Winnicki and Tomasik (1976), were determined.

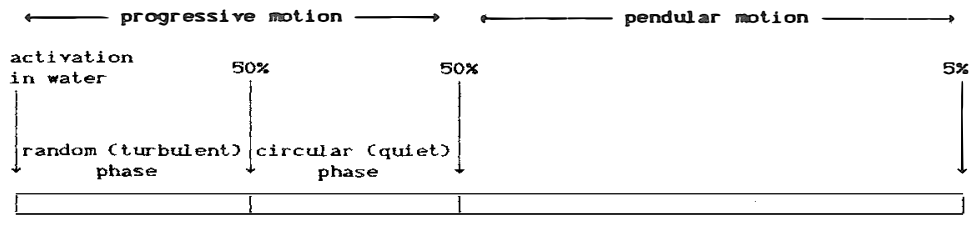

Fig. 1. Motion of Hucho hucho L. spermatozoa after activation (explanation in text)

A total time of spermatozoa motility was number of seconds from an activation moment up to time when there was not more than $5 \%$ spermatozoa with pendular motion within the sample. A progressive motion time started with activation process and lasted to the moment when number of spermatozoa with this type of motion dropped below $50 \%$. Limit of a random (turbulent) phase was determined analogically. Difference between total motility time and progressive motion time was pendular motion time (Fig. 1). Number of active spermatozoa was determined on spermatozoa transition from random (turbulent) phase into a circular (quiet) one.

The spermatozoa motility tests, according to the method by Tomasik (1973) were conducted with optic microscope (enlargement $200 \mathrm{x}$ ). Time of each phase was measured with stoper with $0.5 \mathrm{sec}$ accuracy. Observations were carried out in a cold room, at the temperature around $5^{\circ} \mathrm{C}$, the same as the one in water tanks, were Hucho hucho $\mathrm{L}$. males were being kept (to avoid heating up a sample while on microscope stage).

Spermatocrit was estimated by hematocrit centriruge ( $5000 \mathrm{rpm}$; for $5 \mathrm{~min}$.). Each result of all the tested parameters for each individual is an average of three succesive measures. 
Some of the ejaculates were transported, in cooled thermos container (temp. while transported $5^{\circ} \mathrm{C} \pm 1^{\circ}$ ), to the laboratory at the Institute of Ichthyology, where surveys on spermatozoa motility in the tap water, at $+8^{\circ} \mathrm{C}$ were being continued. Obtained results were worked out statistically.

\section{RESULTS}

Spermatozoa tested were distinguished by relatively high activity (about $70 \%$ of active spermatozoa) with spermatocrit average being $16.7 \%$ (Tab. 1). Progressive motion of spermatozoa, extended in time, lasted about $48 \mathrm{sec}$., where $26 \mathrm{sec}$ was an average time for preliminary phase of that motion - a random (turbulent) one (that is $55 \%$ of a total translatory motion). Progresive motion was then replaced by a relatively long lasting pendular motion ( $84 \%$, that is $64 \%$ of total motility time sof spermatozoa).

Table 1

Spermatoza motility and spermatocrit of Danube salmon,

Hucho hucho L.

\begin{tabular}{|c|c|c|c|c|c|c|c|}
\hline \multirow{3}{*}{$\begin{array}{l}\text { Spe- } \\
\text { cifica- } \\
\text { tion }\end{array}$} & \multirow{3}{*}{$\begin{array}{l}\text { Longitudo } \\
\text { caudalis } \\
\text { (cm) }\end{array}$} & \multirow{3}{*}{$\begin{array}{c}\text { Age } \\
\text { (years) }\end{array}$} & \multirow{3}{*}{$\begin{array}{l}\text { Sperma- } \\
\text { tozoa } \\
\text { activation } \\
(\%)\end{array}$} & \multicolumn{3}{|c|}{ Motion time (sec.)* } & \multirow{3}{*}{$\begin{array}{c}\text { Sperma- } \\
\text { tocrit } \\
(\%)\end{array}$} \\
\hline & & & & \multicolumn{2}{|c|}{ progressive } & \multirow{2}{*}{ pendular } & \\
\hline & & & & $\begin{array}{c}\text { random (tur- } \\
\text { bulent) pha- } \\
\text { șe }\end{array}$ & $\begin{array}{c}\text { circular } \\
\text { (quiet) } \\
\text { phase }\end{array}$ & & \\
\hline $\mathrm{n}$ & 17 & 17 & 17 & 10 & 17 & 17 & 17 \\
\hline $\bar{x}$ & 81.7 & 7.9 & 69.0 & 26.1 & 47.9 & 131.7 & 16.7 \\
\hline SE & 3.6 & 0.6 & 5.4 & 2.2 & 3.4 & 8.0 & 1.5 \\
\hline
\end{tabular}

* spermatoza motion time measured since activation moment

Interesting data were provided by surveys on the spermatozoa motion phases after 24 and 48 hours cold storage $\left(+5^{\circ} \mathrm{C}\right)$ of sperm samples, transported then to the laboratory in Szczecin (Tab.2). Since 24 hours of cold storage a gradual reduction of progressive motion and pendular motion periods was observed, down to about half of its prime value after 96 hours of storage. After 216 hours spermatozoa of only one male showed sings of activity. There was not any sings of a raniom (turbulent) phase of spermatozoa motion observed already 24 hours after the ejaculates caollection. Quite possibly this phase, then, is too short to observe it (within few seconds necessary to get ready for microscopic observations). 
Table 2

Motility of Danube salmon, Hucho hucho $\mathbb{L}$. spermatozoa, when stored

\begin{tabular}{|c|c|c|c|c|c|}
\hline \multirow{3}{*}{$\begin{array}{l}\text { Time since } \\
\text { spermatozoa } \\
\text { colleciton } \\
\text { (h) }\end{array}$} & \multirow{3}{*}{$\begin{array}{l}\text { Specift } \\
\text { cation }\end{array}$} & \multirow{3}{*}{$\begin{array}{c}\text { Spermatozo2 } \\
\text { activation }\end{array}$} & \multicolumn{3}{|c|}{ Motion time $\left(\mathrm{sec}_{.}\right)^{* * * *}$} \\
\hline & & & \multicolumn{2}{|c|}{ progressive } & \multirow[b]{2}{*}{ pendular } \\
\hline & & & $\begin{array}{l}\text { randon (tur- } \\
\text { bulent) phase }\end{array}$ & $\begin{array}{c}\text { circular } \\
\text { (quiet) phase }\end{array}$ & \\
\hline \multirow[t]{3}{*}{$24 *$} & $\mathrm{n}$ & 15 & 10 & 15 & 15 \\
\hline & $\bar{x}$ & 28.2 & 25.1 & 42.9 & 118.2 \\
\hline & SE & 5.96 & 2.74 & 4.3 & 10.7 \\
\hline \multirow[t]{3}{*}{$48 \%$} & $\mathrm{n}$ & 12 & & 12 & 12 \\
\hline & $x^{-}$ & 21.5 & - & 32.3 & 102.7 \\
\hline & SE & 5.18 & & 2.54 & 17.71 \\
\hline \multirow[t]{3}{*}{$96 * *$} & $\mathbb{n}$ & 7 & & 6 & 7 \\
\hline & $\bar{x}$ & 34.3 & - & 24.5 & 52.3 \\
\hline & SE & 5.05 & & 1.58 & 6.9 \\
\hline \multirow[t]{3}{*}{144 * * 우 } & $\mathbb{R}$ & 6 & & 6 & 6 \\
\hline & $\bar{x}$ & 24.8 & - & 24.8 & 51.0 \\
\hline & SE & 7.5 & & 1.74 & 8.1 \\
\hline \multirow[t]{2}{*}{$192 * \%$} & $\mathrm{n}$ & 2 & & 2 & 2 \\
\hline & $\vec{x}$ & 20.0 & & 20.5 & 47.0 \\
\hline $216 * *$ & in & $\mathbb{1}$ & - & - & $\begin{array}{l}\text { not numero- } \\
\text { us }\end{array}$ \\
\hline
\end{tabular}

* surveys at the spawning ground

出s.surveys after transportation to the laboratory

**** spermatozoa motion time measured since activation moment

\section{DISCUSSION}

Observations done, so far, on time of activated Hucho hucho $\mathbb{L}$. spematozoz motion were not numerous and not too precise. Authon were imieresied only the the swernatozon

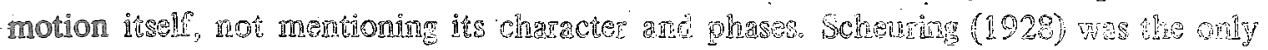

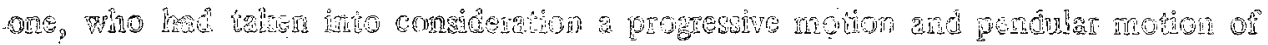

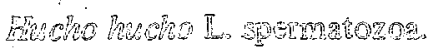

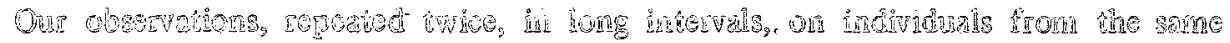

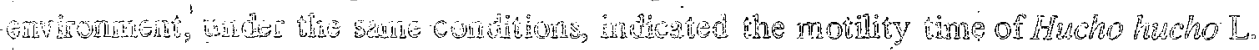
Siptind d

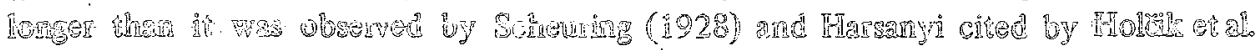


(1984) according to whom motility was observed ing to 120 sec. Therefore, Hucho hucho $\mathbb{L}$. spermatozod activity lasts longer than the one observed for other salmonids. A progressive motion is the most essential from fertilization point of view. According to Smirnov (1954, 1963, 1975) progressive motion of pinis Salmon (Oncorkynchiss gorbuscha) spermatozoa oscilated between 30 and 55 sec., while Caga and Chorevina (1984) found it to last up to $80 \mathrm{sec}$, at temp. 6 to $9^{\circ} \mathrm{C}$. Spematozoa of Oncorhynchuss Reta were in progressive motion for 10 to $15 \mathrm{sec}$. after their activation in water of ternp. $10^{\circ} \mathrm{C}$ (Smirnov, 1975). The same type of motion for spermatozoa of Salmo gairdnevi lastied $23 \mathrm{sec}$. (Billard, 1978) while for Salmo truttu average progressive motion time was 42 sec. (Szymelfenig, 1.979).

Our experiments let us to distinguish two phases within a progressive motiong th Fandom (urbulenit) phase with rapid straight forward movements of spermatozoa and a circular (quiet) one where the motion vibly slows down and enibles to distinguish

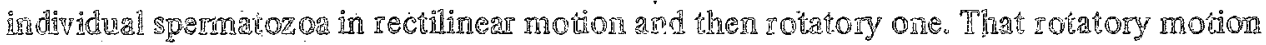

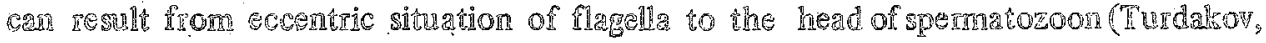

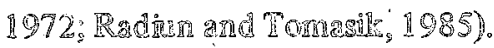

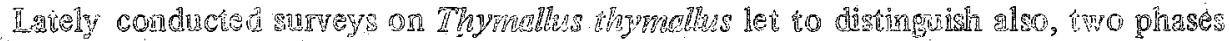

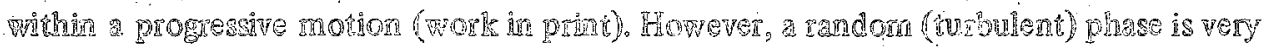
whor ( gec) I

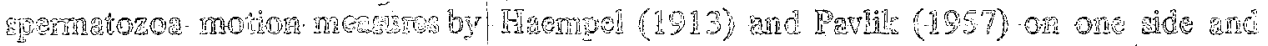

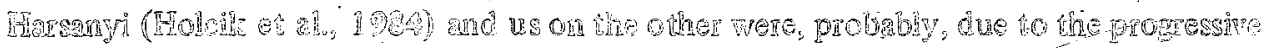

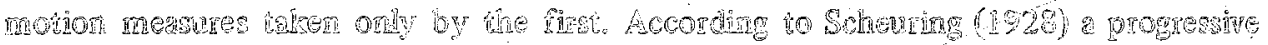

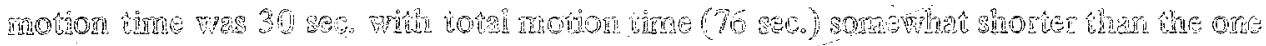

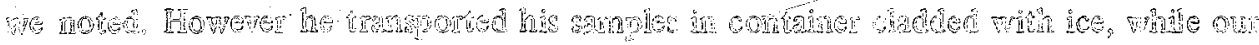

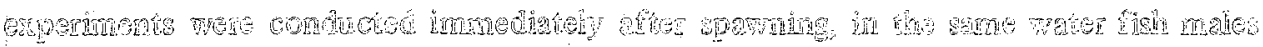

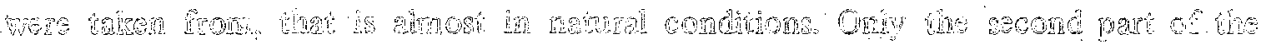

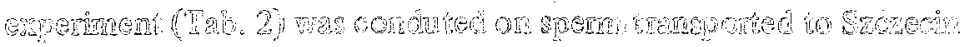

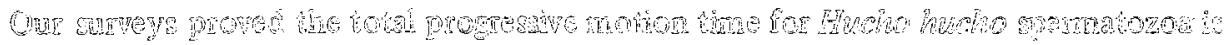

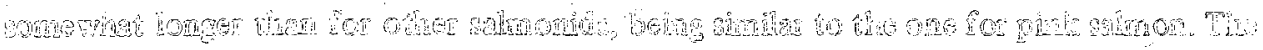

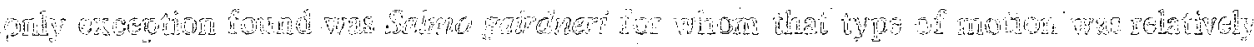

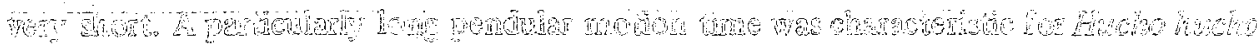

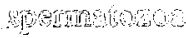

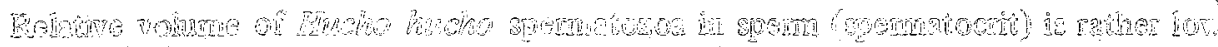

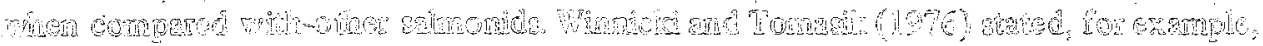

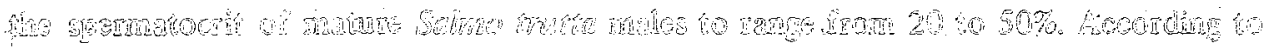

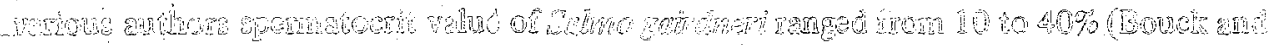

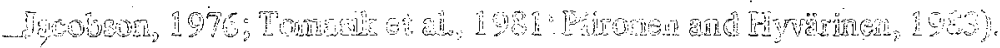

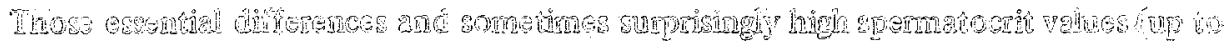

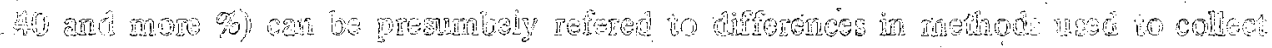

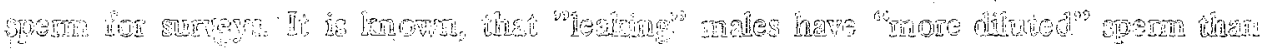

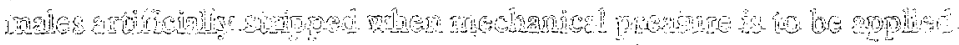


Hence, for the mature Danube salmon (Hucho hucho, L.) males percent of spermatozoa activation is rather high (70\%), while spermatocrit relatively low (17\%). Immediately after spawning a random (turbulent) phase of progressive motion is cearly distinguished and the total motion time of spermatozoa equals to $130 \mathrm{sec}$. During cold storage of sperm, spermatozoa stay viable for a long time.

\section{REFERENCES}

Billard R., 1978: Changes in structure and fertilizing ability of marine and freshwater fish spermatozoa diluted in media of various salinities. - Aquacult., 14: 187-198.

Bouck G.R., J. Jacubson, 1976: Estimation of Salmonid Sperm Concentration by Microhematocrit Technique. - Trans. Amer. Fish. Soc., 105: 534-535.

Caga I.L., N.B. Chorevina, 1984: Ekologicekije osobennosti vosproizvodstwa kety, nerki i gorbusi. Biologia moria, no 6: 27-31 (in Russian).

Haempel O., 1913: Fische I. Allgemeine anatomisch-physiologische übersicht. 11. Die Fortpflanzunsorgane. - in: Hildheimer M.: Handbuch der Biologie der Wirbeltiere, Stuttagrt, Verl. Ferd. Enke: $65-74$.

Holcik J., K. Hensel, J. Niesladnik, 1984: Hlavatka. Bratislava, Veda (in Czech).

Holtz W., J. Stoss, S. Bütykü khatipoglu, , 1977: Beobachtungen zur Akivierbarkeit von Forellenspermatozoen mit Fruchtwasser, Bachwasser und destillierten Wasser.- Zuchthygiene, 12: 82-88.

Nomura M., 1964: Studies on reproduction of rainbow trout Salmo gairdneri, with special reference to egg taking. VI - The activities of spermatozoa in different diluents, and preservation of semen. - Bull. Jap. Soc. Sci. Fish., 30:723-733.

Pavlik I., 1957: Umely vyter hlavatek. - Cs. rybarstvi, 12: 71 (in Czech).

Piironen .J., A. Hyvärinen, 1983: Composition of milt of some teleost fishes. - J. Fish. Biol., 22: $351-361$.

Radziun K., L. Tomasik, 1985: Ultrastructure of Hucho hucho (L.) spermatozoa. - Acta Ichthyol. Pisc., 15(2): 130-140.

Scheuring L., 1928: Weitere biologische und physiologische Untersuchungen an Salmonidensperma. Zool. Jb., Abt. zool. physiol., 45: 651-705.

Smirnov A.I.: 1954: Nabludenija nad producirovanijem molok tichookeanskimi lososiami. - Izv TINRO, 42: 159-164 (in Russian).

Smirnov A.I.: 1963: Producirovanije spermy tichookeanskimi lososiami roda Oncorhynchus. - Vopr. ichtiol., 3: 84-98 (in Russian).

Smirnov A.I., 1975: Biologija, rozmnożenije i razvite tichookeanskich lososej, Moskwa, Izd. Moskovsk, Universiteta (in Russian).

Szymelfenig M., 1979: Wpływ wody morskiej o różnych zasoleniach na plemniki i jaja pstrąga tęczowego (Salmo gairdneri Rich. 1836) i troci wędrownej (Salmo trutta trutta L. 1758. [Effect of sea water of different salinity on spermatozoa and eggs of Salmo gairdneri Rich. 1836 and Salmo trutta trutta L. 1758.] - Zesz. nauk. Wydz. Biol. i Nauk o ziemi Uniw. Gdańskiego (Oceanografia), 6: $129-146$.

Tomasik L., 1973: Specific and individual differences in motility between salmonid spermatozoa. Acta Ichthyol. Pisc., 3; 1: 11-17.

Tomasik L., A. Sobociński, A. Winnicki, 1981: Spermatokryt jako wskaźnik w badaniach nasienia ryb. [Spermatocrit as an indicator in surveys of fish semen]. In main surveys conducted at the Faculty of Marine Fisheries and Food Technology in 1970-1980 Szczecin, Summary: 110-114. 
Turdakov A.F., 1972: Vosproizvoditelnaja sistema samcov ryb. - Izd. Ilim. Frunze. (in Russian). Winnicki A., L. Tomasik, 1976: "Spermatocrit" as a method for biological evaluation of fish sperm. Acta Ich thyol. Pisc., 6, 2: 3-8.

Yoshida T., M. Nomura, 1972: A substance enhancing sperm motility in the ovarian fluid of rainbow trout. - Bull. Japan. Soc. Scient. Fish., 38: 1073.

Translated: Dr E. Daczkowska-Kozon

Formicki Krzysztof, Kowalewski Mieczysław, Sobociński Andrzej.

Tomasik Lucjan, Winnicki Aleksander

RUCHLIWOŚĆ PLEMNIKÓW GŁOWACICY (HUCHO HUCHO L.) PO AKTYWACJI

STRESZCZENIE

W latach 1985 i 1988 przeprowadzono obserwacje ruchliwości i spermatokrytu plemników 17 samców głowacicy (Hucho hucho L.). Stwierdzono, że względna ilość aktywnych plemników w spermie jest znaczna (średnio 70\%), a spermatokryt (względna objętość plemników w spermie) niski (średnio $16.7 \%$ ) $\mathrm{w}$ porównaniu $\mathrm{z}$ innymi rybami łososiowatymi. Bezpośrednio po tarle, wśród zaaktywowanych plemników wyraźnie zaznaczona jest faza burzliwa ruchu postępowego. Całkowity czas ruchu plemników wynosi średnio 130 sek, z czego na ruch postępowy przypada ok. 37\% (śr. 48 sek.).

Plemniki w spermie przetrzymywanej w temp. $8^{\circ} \mathrm{C}$ zachowują żywotność do 216 godz.

Author's address:

Received: 1988.09 .23

Prof. dr hab. Aleksander Winnicki

Dr Krzysztof Formicki, Dr Lucjan Tomasik,

Mgr inż. Andrzej Sobociński

Akademia Rolnicza

Insty tut Ichtiologii

ul. K. Królewicza 4

71-550 Szczecin (Poland)

Mgr inż. Mieczysław Kowalewski

Polish Angling Union

Fishery Station at Łopuszna

34-432 Łopuszna 192, Poland 